\title{
MEDICAL TUBERCULOSIS IN UKRAINE IN 2018
}

\section{Daria Makarenko ${ }^{1}$ Sofia Shvid ${ }^{2}$}

\section{DOI: https://doi.org/10.30525/978-9934-588-39-6-27}

Priority. Ukraine is among the ten countries with the highest level of multidrug-resistant tuberculosis in the world. Despite the introduction of new approaches to the therapy of tuberculosis, an analysis of the situation shows the lake of approaches in the provision of TB care to the population.

Nowadays the real problem is the high level of tuberculosis among medical workers. Medical workers can catch tuberculosis both in anti-TB institutions (dispensaries, hospitals, sanatoriums), and in general medical facilities where contact with bacilli or contaminated material is possible (departments of thoracic surgery, pathology departments and forensic medical bureaus).

Goal. To study the problem of the incidence of tuberculosis of medical workers in Ukraine in 2019.

Materials and methods. Analysis and synthesis of analytical and statistical materials of the Ukrainian Public Health Center.

It should be noted that it is the observance of infection control measures that is important: the rules of personal safety of medical workers and modern equipment.

Results. In 2018, in Ukraine, 46 cases of tuberculosis were recorded among medical workers in the medical facilities providing care for patients with tuberculosis (220 cases per 100 thousand people) and 382 cases among medical workers of general medical institutions (60 per 100 thousand people), while the average incidence of tuberculosis in the population of Ukraine for this period was 50.5 per 100 thousand people. In some areas, the rate of tuberculosis among employees of medical care facilities in the TB department reaches several hundred cases per 100,000 population.

If we take a look at the rate of tuberculosis in Ukraine among employees of healthcare institutions during 2018, it become lower up to 0,4 incidents per 10,000 employees of healthcare institutions. (If we take a look at the level of tuberculosis in Ukraine among employees of medical care institutions, then it decreased by $6.3 \%$ (from 6.4 to 6 cases per 10 thousand people).

\footnotetext{
${ }^{1}$ Kharkov National Medical University, Ukraine

${ }^{2}$ Kharkov National Medical University, Ukraine
} 
The incidence of TB in the Kharkiv region among medical workers is the smallest compar with other regions of Ukraine. This result can be achieved by strict following the rules of infection control.

The level of equipment with bactericidal lamps (open, shielded and combined type) in 2018 reached 91.1\% (in 2015 - 56\%, 2016 - 69.8\%, 2017 - 84.3\%). Despite the increase in the number of bactericidal lamps, some bactericidal lamp require replacement, and some are not installed and are in stock.

In 2017, new ventilation systems were installed in the TB institutions of the regions of Ukraine, namely general ventilation, as well as updated local ventilation. In addition, there was an upgrate of open type bactericidal lamps. This contributed to a decrease in the rate of tuberculosis among medical workers, as evidenced by statistical data: in 2015, the incidence of TB among healthcare workers in Ukraine (including TB dispensaries) per 100 thousand employees of healthcare institutions was 63.4, and in $2016-60$ 6, which is higher than the level of tuberculosis 2018 year.

According to the reported data, the supply of respirators, namely the supply of respirators for the number of months in the regions, is 4.53 respirators per person, based on 1 respirator for approximately 8 hours of work.

Conclusions. The level of tuberculosis among medical workers remains an impotant problem of our time. To prevent morbidity of tuberculosis, it is impotant to equip in places of stay of patients with tuberculosis modern equipment ventilation, as well as bactericidal lamps. It is important to observe the rules of personal hygiene, a responsible attitude to their safety, and the provision of respirators for workers.

\section{References:}

1. Barbova, A. I. (2016). Sovremennyye podkhody k diagnostike multirezistentnogo tuberkuleza [Modern approaches to the diagnosis of multidrug-resistant tuberculosis]. Ukr. pulmonol. zhurn., no. 2, pp. 28-29. (in Russian)

2. Bektasova, M. V. (2015). Otsenka i upravleniye professionalnymi riskami kak osnova profilaktiki professionalnoy zabolevayemosti meditsinskogo personala (na primere Primorskogo kraya): avtoreferat dissertatsii doktora meditsinskikh nauk: 14.02.01. [Estimation and management of professional risks as a basis of prophylaxis of occupational morbidity of medical personnel (on an example of Primorsky Region): the author's abstract of the dissertation of the doctor of medical sciences: 14.02.01]. Moscow, pp. 17-19. (in Russian)

3. Vaganova, U. S. (2015). Zabolevayemost tuberkulezom rabotnikov meditsinskikh uchrezhdeniy [Incidence of tuberculosis in health care workers]. Klinicheskaya meditsina, no. 2, pp. 67-72. (in Russian) 